\title{
Die terugkeer van die paradys en skepping. Oor nuwe aandag vir Joods-Christelike interpretasies van die paradys-motief
}

\begin{abstract}
The return of paradise and creation. On recent attention for Jewish-Christian interpretations of the paradise motif

This article investigates several aspects of the renewed interest in paradise in recent research. It outlines the growing lack of interest, especially since the Enlightenment in the motif of paradise. It provides reasons for the renewed interest in it in recent reseach and it then lists some complex results of this research. It discusses biblical material on paradise before it investigates in more detail three foundational aspects of paradise. These include paradise as a spatial reality and as crucial moment in the history of the divine act of salvation. It ends with a discussion of the salvific understanding of paradise.
\end{abstract}

\section{INLEIDING}

In 1991 het Vincent Brümmer, in die inleiding tot sy geredigeerde werk met die titel, Interpreting the universe as creation: A dialogue of science and religion, gewys op die belangrike uitdagings wat die skeppingsmotief aan geloof stel, wat, onder andere, die vraag (1991:1) insluit: "Do religion and science produce rival explanations of the same phenomena? If so, which explanation is the correct one? Is the doctrine of creation an obsolete religious myth which has now been superseded by the verifiable theories of science?"1 Hierdie belangrike vrae roep binne die Bybelwetenskappe ook om besinning, veral in die lig van die belangrike plek van die skepping in Bybelse tekste. Die skeppingsmotief word veral deur die paradysverhaal aan die orde gestel. In die persepsie van vele Bybellesers roep die paradys-motief veral assosiasies met Genesis 1-3 op en kan daarom maklik verwaarloos word. Dit is nie verbasend nie, want die paradys word uitdruklik slegs in twee ander dele van die Bybel genoem.

Die drie verwysingsplekke word egter belangriker wanneer hulle vanuit die perspektief van die Bybelse tekste as kanon gelees word. Die paradys-vertelling aan die begin van die Ou Testament in Genesis 1-3 word dikwels in samehang met die besondere uitbeelding van die paradys aan die slot van Openbaring 22 verbind. Ewe opmerklik is dat die paradys-motief ook in die middel van die kanon prominent na vore kom wanneer Jesus aan die einde van die versoekingsverhaal in die woestyn deur die engele gevoed word en saam met die wilde diere verkeer (Mk. 1:13; Mt. $4: 11) .{ }^{2}$ Hierdie rangskikking van die kanon illustreer die belangrike plek van die paradys vir latere

1 Met hierdie artikel wil ek graag die jubilaris vereer vir sy jarelange bydrae tot die teologie en, veral in onlangse tye, sy belangrike insigte op die gebied van spiritualiteit. In lg. verband dink ek met besondere waardering aan sy belangrike boek oor gebed (2011) en sy bydrae tot die verstaan van die vroeë geskiedenis van spiritualiteit in ons land.

2 Kyk Wall (1991: 20) vir die verhouding tussen Genesis en Openbaring vanuit kanonieke perspektief en Fry \& MacPherson 2004: 30-31 vir algemene teologiese opmerkings oor die verband tussen Genesis en 
lesers. Hoe gewild die motief was, blyk origens uit die ongebreidelde spekulasies oor die paradys wat mettertyd in nie-ortodokse groepe posgevat het. So ' $n$ omvang het hulle aangeneem dat Rabbiniese kringe doelbewus ' $n$ ortodoksie ontwerp het wat die verstaan van die paradys moes begelei. $^{3}$

Die paradys het reeds vanaf die vroegste tye die beste denkers besig gehou, al was dit ook vanuit ' $n$ kritiese hoek. Die geleerdes was deeglik bewus van die probleme wat Genesis se paradysverhaal oproep. Philo van Alexandrië het byvoorbeeld, in 'n "buitengewoon wetenskaplike bespreking" verwys na die bekende argumente dat daar in geskrifte voor en in sy tyd geen verwysings na ' $\mathrm{n}$ paradys in die area van die Tigris en die Eufraat was nie (Niehoff 2010:41). Hy het die probleem opgelos deur te skryf dat die paradys in die nie-bewoonde wêreld geleë was en daarom in sulke bronne onvermeld gebly het. Dit onderstreep volgens hom dat die paradys buite alle menslike berekeninge en kaarte val. Origens het hy teenstrydighede in die Genesis-verhaal deur allerhande simboliese en allegoriese interpretasies opgelos. ${ }^{4}$ Sy bespreking van die paradys toon dus in hoeveel besonderhede die paradys-verhaal reeds in sy tyd krities beoordeel is.

Hierdie uitgebreide belangstelling sou nog vir 'n lang tyd voortduur. Die spesiale aandag aan die paradys in latere tye word byvoorbeeld bevestig deur die uitgebreide interpretasiegeskiedenis van die paradys in die Jodedom en Christendom - nie net in die sinagoge en kerk nie, maar ook in musiek, beeldende kuns en literêre werke. Beroemde voorbeelde uit veral die latere Westerse konteks is byvoorbeeld Brueghel en die Van Eijck broers se skilderye, Dante se Goddelike Komedie, Milton se Paradise lost en Haydn se Skepping. ${ }^{5}$

Dit is eers sedert die Verligting dat - ook in teologiese konteks - minder aandag aan die paradys-motief bestee is, veral omdat Bybelse verwysings na die paradys, en, in ' $n$ groter verband, die skeppingsverhaal, dikwels beskou is as naïewe, letterlike vertellings vanuit ' $n$ mitopoëtiese wêreldbeeld - ' $n$ proses wat in Brümmer se pertinente vraag gereflekteer word.

Ook die Bybelwetenskappe het veral in die histories-kritiese era nie veel publikasies oor die tema opgelewer nie. ${ }^{6}$ Die relatiewe geringe belangstelling in die paradys-motief is ook die resultaat van ' $n$ bepaalde teologiese perspektief in sekere teologiese kringe van die twintigste eeu. Vir ' $n$ geruime tyd is die paradysverhaal en die skeppingsberig waarin dit tuishoort, uitdruklik as ' $n$ ondergeskikte tema in Bybelse denke beskou. Die dialektiese teologie het, in hulle verset teen ' $n$ natuurlike teologie, eerder die heilsmotief as sentrale fokus van die Bybel en veral van die Ou Testament uitgelig en ten koste van die skeppingsmotief beklemtoon. ${ }^{7}$ Die

Openbaring. Die implikasies van die intertekstuele verbinding is raakgesien deur Neville (2007: 133-134) wat daarop wys dat die Bybelse perspektief op geweld verstaan moet word teen die agtergrond van die feit dat die begin, middel en einde van die Christelike verhaal in terme van die paradys-motief uitgebeeld word en dus vrede as ' $\mathrm{n}$ deurlopende en dominante gedagte in die Bybel presenteer.

3 Stroumsma (2010: 3 ) verwys na sulke poging in vroeë Joodse en Christelike tradisies.

4 Niehoff (2010: 28-56) toon aan hoe Philo op ' $n$ innoverende manier beide die letterlike en die allegoriese interpretasie in balans hou. Hy ontleed die Genesis-verhaal oor die paradys in sy geheel, vra vrae oor die moontlike teenstrydighede daarin (Niehoff 2010: 32-33) en gee dan allegoriese interpretasies wat die teenstrydighede verklaar. God se waarskuwing in Genesis 2:17 dat ongehoorsaamheid aan die gebod om van die boom van die lewe te eet tot die mensepaar se dood sal lei, is nie teenstrydig met die latere berigte dat Adam en Eva nog lewe en selfs kinders het nie (Gen.4:1). Hulle is, verklaar Philo, geestelik wel dood deur hulle bose lewensstyl (Niehoff 2010: 33). Wat Philo se allegoriese verklaring soveel interessanter mak is sy opmerking dat die skrywer self die allegoriese bedoeling in gedagte gehad het.

5 Kyk Bouma (2012) vir ' $n$ bespreking van die spesiale plek van die paradys in Middeleeuse denke.

6 Bauckham (1988: 473) het al met "n stuk ironie opgemerk dat die paradys selfs nog minder as die hel nagevors is.

7 Sien die bespreking in Rendtorff (1992: 205). Von Rad (1936) is 'n goeie voorbeeld van die fokus op die heilsgebeure as sentrale tema in die Ou Testament. Dit is ironies dat, terwyl hy die skeppingsteologie 
proses is aangehelp deur die wydverspreide, modernistiese neiging om een "sentrale" motief as bindende faktor vir ' $n$ teologie van die Ou en Nuwe Testament uit te lig. Dit het die waarde van die skeppingsverhaal met sy paradys-motief onvermydelik verder aangetas.

Die situasie is egter besig om te verander. Teen die einde van die twintigste eeu was daar aanduidings van ' $n$ ommekeer, veral met die groter ontginning van voorheen onbekende of ontoeganklike apokaliptiese werke waarin die paradys ' $n$ belangrike rol speel (De Villiers 2009:1739). Maar ook die groter belangstelling in Bybelwetenskaplike kringe in die teologiese boodskap van die Bybel het gehelp om die tema sterker na vore te bring. ${ }^{8}$ Die groeiende ekologiese bewussyn in resente tye is ook besig om belangstelling in die skepping en paradys te stimuleer.

Die resultaat hiervan was meer aandag vir die implikasies van die skeppingsmotief en, ook, enkele belangrike werke wat uitsluitlik op die paradys as tema gefokus het. Bekend is byvoorbeeld die meer algemene en oorsigtelike driedelige werk van die Franse historikus, Jean Delumeau oor hoe die paradys in Westerse kontekste geïnterpreteer is (1992; in Engelse vertaal in 1995). Daar was in die Bybelwetenskappe relatief meer beweging. In 1999 was daar ' $n$ hele aantal bydraes van verskeie navorsers, hoofsaaklik uit Nederlandse konteks, in ' $\mathrm{n}$ bundel onder die titel Paradise interpreted: representations of biblical paradise in Judaism and Christianity. Besonder waardevol was origens twee bydraes van Scafi (2006 en 1999). In die mees onlangse publikasie van Bockmuehl en Stroumsa (2010) het 'n opmerklike groot groep navorsers weer eens die motief onder die loep geneem. In al hierdie publikasies kom die prominente plek van die paradys in die interpretasie-geskiedenis van die Bybel op ' $n$ spesiale manier tot sy reg en word die komplekse, belangrike rol daarvan uitgespel. ${ }^{9}$

Veral een oorheersende indruk word deur hierdie werke geskep. Al die insigte in die Joodse en Christelike resepsie-geskiedenis wys dat die paradys-motief ' $n$ digte kompleks van verskillende inhoude en motiewe vorm. ${ }^{10}$ Die kompleksiteit wys op sy beurt ook hoe noukeurig, maar ook dikwels hoogs kreatief, mense deur die geskiedenis die oorspronklike paradys-verhaal gelees en geïnterpreteer het.

Hierby bly dit egter nie: Ewe boeiend is dat resepsies van die verhaal weer daartoe bydra dat die Bybelse verwysings na die paradys met nuwe oë deur lesers gelees kan word. Dit is daarom van belang om meer aandag aan navorsing oor en inhoud van die motief te gee sodat meer reg daaraan kan geskied as wat tans die geval is.

Die doel van hierdie artikel is daarom om navorsing oor die kompleksiteit van die paradysmotief met al sy verskillende dimensies onder die loep te neem, die Bybelse verwyings na die paradys opnuut te ondersoek in hulle groter verbande en om die teologiese-spirituele betekenis van hierdie insigte uit te spel. Spesiale aandag word gegee aan die ruimtelike, historiese en soteriologiese aanbieding van die paradys-motief en die manier waarop hierdie motief nog ter sake vir ons tyd is. Hiervoor word veral die noue band tussen skepping en paradys geëvalueer.

\footnotetext{
nie as ' $n$ tema in eie reg in die Ou Testament sien nie, die skeppingstekste tog in sy denke ' $n$ belangrike rol speel, soos Rendtorff aantoon. Origens is dit ook duidelik dat sekere misvattinge " $\mathrm{n}$ rol in Von Rad se resepsie van skeppingstekste gespeel het. Brueggeman (1996) het daarop gewys dat die dialektiese relativering van die skeppingsgedagte by Von Rad (onder invloed van Barth) die gevolg was van sy foutiewe siening van die Nazi-ideologie as ' $n$ vorm van natuurlike teologie. Kyk hieroor ook Barr (1993: 112-113).

8 Kyk bv. Brümmer (1991: 16) se samevatting van die Ou-Testamentiese bydrae in sy geredigeerde bundel waarin hy klem lê op die teologiese implikasies van die skeppingsverhaal (sien verder hieronder).

9 Kyk ook Goris \& Hennecke (2005).

10 Hierdie elemente is in latere tye elkeen in ' $n$ bepaalde situasie oorgeneem en verklaar, maar nie soseer om na te dink oor wat die paradysverhaal oorspronklik beteken het nie, maar om tema's en probleme van latere lesers in hulle konteks aan te spreek. Die gevolg hiervan is dat die paradyse-tema besonder gevarieerd geraak het (Stroumsa 2010: 1-14).
} 


\section{DIE PARADYS-MOTIEF IN SY KOMPLEKSITEIT}

Hoewel die gegewens oor die paradys in die Ou Testament hoofsaaklik beperk is tot Genesis, is dit ' $n$ verhaal wat ryk is aan detail, soos ' $n$ noukeurige lees van die teks, maar ook die resepsiegeskiedenis daarvan uitwys. Elkeen van die vele motiewe het by latere lesers ' $n$ magdom van interpretasies opgeroep, waarmee die rykheid en betekenis-surplus van die oorspronklike verhaal uitstekend geïlustreer word. Die woord "paradys" verwys oorspronklik na die tuin in Genesis 2-3 waar God die mens plaas na hulle skepping (Gen. 2:8). ${ }^{11}$ Die tuin word in Eden, in die Ooste gelokaliseer en aan die begin van die tye getemporaliseer. Ook die res van die oënskynlike sober verhaal bevat motiewe wat tot uitgebreide kommentaar aanleiding gegee het. In die tuin wandel God self (Gen. 3:8), die mens werk daar (Gen. 2:15) en word na die sondeval daaruit verdryf (Gen. 3:23). Die paradys word as 'n besondere plek uitgebeeld: Daar staan bome, mooi om na te kyk en lekker om van te eet, waaronder die boom van die lewe en die boom van alle kennis (Gen. 2:8). Die tuin is egter nie onvoorwaardelik vir die mens se bewoning beskikbaar gestel nie. Van die boom van kennis mag niemand eet nie (Gen. 2:17; vgl. 3:3). Omdat die mens die opdrag verontagsaam, word hulle die tuin belet. Na die vertrek van die mens is die tuin deur gerubs bewaak. Die boeiende beeld van die gerub se vlammende swaard "wat heen en weer beweeg" wat toegang tot die tuin afsluit, sou ook tot eindelose kommentaar aanleiding gee (Gen. 3:24). ${ }^{12}$

Tog toon sekere onlangse insigte in intertekstuele lyne tussen die paradys-verhaal en latere literatuur dat die paradys-motief nie net met Genesis 2-3 verbind moet word nie. Kister (2010:138-55) wys byvoorbeeld daarop hoe die paradysverhaal in die res van die Ou Testament deurskemer met die oorname van die motief van die boom van die lewe in Jesaja 65, Jeremia 17 en Psalm 1. 'n Soortgelyke situasie bestaan ten opsigte van die Nuwe Testament. Direkte verwysings na die "paradys" lyk op die oog af ook beperk. ${ }^{13}$ In Lukas 23:43 belowe Jesus aan sy mede-kruiseling dat hy daardie dag nog saam met Jesus in die paradys sou wees ${ }^{14}$ Heel anders word van die paradys gepraat in 2 Korintiërs 12:4 waar Paulus vertel van ' $n$ uitsinnige ervaring toe hy in die paradys in die derde hemel weggeruk is en onuitspreeklike woorde gehoor het (2 Kor. 12:2). ${ }^{15}$ 'n Derde variasie kom voor wanneer ' $n$ heel ander motief in Openbaring 2:7 oorgeneem word. Hier word die gelowiges beloof dat God aan die wat oorwin sal gee om van die boom van die lewe te eet. Die belofte word vervul in Openbaring 22:2 wanneer die hemelse paradys terugkeer.

In resente bydraes word egter gewys hoe paradys-motiewe op ander maniere in die Nuwe Testament inwerk. Die belangrikste hiervan is die prominente rol wat die figuur van Adam in Paulus se Christologie speel (Macaskill 2010:64-65). ${ }^{16}$ In 'n boeiende bydrae, argumenteer Schaper (2010:17-27) dat Johannes-Evangelie, meer as die ander Evangeliste, klem lê op die rol van die tuin in Jesus se lewe. Ook hy verbind hierdie tuin-motief met die Adam-figuur as koninklike tuinier in Genesis 2:3. Wanneer Johannes-Evangelie dit oorneem, is dit ' $n$ simbool van Jesus se koninklike messiaanse status. ${ }^{17}$ In nog 'n Johannese teks, word, soos Van Houwelingen

11 Vir ' $\mathrm{n}$ betekenis van die woord paradys, sien die uitgebreide bespreking by Bremmer (1999: 1-20).

12 Kyk Noort (1999) vir ' $n$ uitgebreider bespreking van die Ou-Testamentiese gegewens oor die paradys.

13 Kyk Bietenhard (1979: 997-8) en Jeremias (1954: 763-71) vir 'n eksegetiese bespreking.

14 Volgens Goodman (2010) is Lukas 23:42 sonder enige parallelle in vroeë Joodse literatuur. Lukas is dus een van die eerste tekste wat oor die paradys dink in terme van die onmiddellike post-mortem bestaan.

15 Kyk vir ' $n$ bespreking ook Bouma (2012) en veral sy opmerkings oor die plek daarvan in die destydse wêreldbeeld.

16 Paulus se aandag aan die Adam-motief is nie uniek nie. Dit gebeur ook in ander werke, soos bv. 2 Barug en 4 Esra. Kyk bv. Hense (2011: 173-4).

17 Hoewel Zimmerman (2006:22) die simboliese betekenis van die tuin in Johannes-Evangelie verwerp, is 
(2011:1-15) uitgewys het, ten minste sewe verskillende aspekte van die paradys-verhaal oorgeneem, al verwys dit slegs 'n enkele keer uitdruklik na die woord paradys. ${ }^{18}$ Dus is die rol van die paradys in die Bybel nie net meer prominent as wat soms gedink word nie, maar ook reeds kompleks.

Die voorkoms van die paradys-motief in buite-Bybelse literatuur bevestig hoe belangrik dit vir latere skrywers was, maar ook hoe kompleks dit geresepteer is. Soms is die interpretasies van die paradys-verhaal uniek. Bauckham (2010:43-56) bespreek byvoorbeeld hoe Pseudo-Philo in sy Bybelse Oudhede skryf dat die twaalf sierstene op die Hoëpriester se kleed uit die paradys afkomstig was, spekuleer oor die paaie van die paradys wat na die boom van die lewe lei, vertel van Moses se toer van die laer hemel wat by die paradys eindig en sy lesers meedeel dat die hout wat Moses in die water by Mara gooi, van die boom van die lewe afkomstig was. Kister (2010:138-55) wys daarop hoe latere lesers uitvoerig op Genesis 3:24 se verwysing na die gerub se vlammende swaard wat heen en weer beweeg, kommentaar gelewer het. Inowlocki (2010), weer, ondersoek die effek van die paradys-verhaal op die siening van die wet in latere JoodsChristelike tekste. Hy bespreek hoe skrywers soos Tertullianus op grond van Genesis 2:16-17 gespekuleer het oor die verband van die natuurlike wet in die paradys met latere wetgewing aan die aartsvaders, Moses en die evangelie. Terwyl Openbaring die toekomstige paradys sien as ' $n$ gawe van God aan hulle wat getrou bly, word die paradys in Rabbiniese literatuur van die vierde en vyfde eeu gesien as ' $n$ gawe van God wat deur seksualiteit en die verwekking van kinders teruggekry kan word (Hasan-Rokem 2010:156-165).

Reeds hierdie kort oorsig wys hoedat die inhoud van die paradys-verhaal ver verby die kort vorm daarvan in Genesis 2-3 op latere lesers ingewerk het. Elke detail van die verhaal is uitgelig, geherinterpreteer en op nuwe manier bevraagteken en ondersoek. In sommige gevalle, soos by Paulus, het die paradys-verhaal verreikende teologiese invloed uitgeoefen.

\section{DIE PARADYS AS PLEK}

Die komplekse geheel van uitsprake oor die paradys kan moeilik in 'n patroon gesistematiseer word. Die kompleksiteit is vererger omdat latere lesers hulle uitleg van Bybeltekste gebruik het om hulle eie situasie te verklaar of om hulle teenstanders te diskwalifiseer. In die proses is die paradys-motief ver verby die oorspronklike konteks waarvan dit deel was, gevoer en ontwikkel. Tog staan sekere aspekte uit, waarvan sommige van spesiale belang in 'n kontemporêre konteks is.

Uitleggers het die paradys steeds verstaan as ' $n$ werklike, soms selfs letterlike en geografiese plek in die verlede, hede en toekoms. Dit is steeds weer binne die skeppingsverhaal gelees en geïnterpreteer as deel van God se werk wat 'n ruimte vir natuur en mens geskep het. Die opvatting van paradys as ' $n$ plek kan verbind word met die Bybelse gegewens in Genesis 2-3 waar dit deur ruimtelike inligting (bv. van die vier riviere) op aarde gesitueer word. Die lokalisering word ook in die Nuwe Testament aangedui: In Lukas 24:34 is die paradys ' $n$ plek waar mense na hulle dood woon. In 2 Korintiërs 12:2 en 4 is die paradys weer eens spesifiek 'n plek, maar hier is dit ' $n$ plek in die derde hemel. ${ }^{19}$

dit moeilik denkbaar dat hierdie motief bloot as ' $n$ detail-opmerking ingevoeg is.

18 Dit sluit in verwysings na die nuwe hemel en aarde, God en die Lam as ewige ligbron, diensknegte wat as konings regeer, toegang tot die boom van die lewe, die rivier van lewende water, kosbare edelstene en die oorwinning oor die draak-slang.

19 Bouma (2012) bepreek die aanspraak in die Joodse kosmologie dat daar sewe hemele is. Die derde hemel word met die liggaamlike teenwoordigheid van mense in die hemel geassosieer. "A grander claim would seem to include rapture to a higher heaven where the presence of God is more palpable." In die Griekse kosmologie is daar drie (soms vier) hemelse sfere. Die hoogste sfeer was gewoonlik die 
Die uiteenlopende lokaliserings van die paradys in die hemel en aarde is nie ongewoon nie en kan ook nie in terme van 'n moderne wêreldbeeld verstaan of geproblematiseer word nie. In die destydse Grieks-Romeinse konteks word die paradys in pseudepigrafiese literatuur ook op aarde (1 Hen.23:3; Jub.4:23) of in die hemel (2 Bar.4:2-7) geplaas (Rowland 1982:170). Vir die hemelse lokalisering is daar ' $n$ duidelike rede. Die paradys is volgens sommige skrywers in die hemel as gevolg van die feit dat die paradys weens die sondeval weggeneem is. Daarom bestaan dit vir hierdie geskrifte in 'n ontoeganklike, verborge plek wat of op ' $n$ hoë berg of in die hemel weggesteek is. ${ }^{20}$ Die hemelse sfeer het vir antieke skrywers dieselfde fisieke werklikheid gehad as die aardse. Die paradys wat in 4 Esra 7:36, 123 en 8:52 ook in die hemel gelokaliseer word, is byvoorbeeld terselfdertyd ' $n$ "werklike" plek met blomme, vrugte en bome. In 2 Henog 42:3 is die paradys in die ooste van die aarde wat oop tot sover as die derde hemel is (Moo 2011:51-52).

Die paradys as plek word beter begryp in die lig van antieke kosmologie, veral soos dit in apokalipse voorkom. Apokaliptiek, as literatuur wat hemelreise ingesluit het, het 'n besonder belangstelling in kosmologie en astronomie gehad en was gekenmerk deur allerhande spekulasie oor natuurverskynsels. ${ }^{21}$ In die tekste reis ' $n$ siener van die aarde deur die hemele en ervaar allerhande besondere openbaringe oor die samestelling van die kosmos. Hierdie verborge kennis is veral deur en tydens hemelreise aan ' $\mathrm{n}$ regverdige mens bekend gemaak waar aan die siener allerhande insigte oor die skepping, insluitende die paradys, geskenk is. ${ }^{22}$ Deur hierdie kosmologiese perspektief word apokalipse en spesifiek die paradys sterk met die skepping verbind. Apokalipse is dus, anders as wat dikwels gedink word, juis nie tekste wat bloot oor die toekoms handel nie, maar hulle het 'n sterk kosmologiese bewussyn, dink na oor die wêreld as God se skepping en sien hierdie ander wêreld as ' $n$ alternatief op die huidige verdorwe, verganklike wêreld. Nie net die mens nie, maar ook die wêreld word deur God tot sy oorspronklike bedoeling getransformeer. Dit behels veral dat dit bestaan tot aanbidding van God.

Hierdie werklikheid en sy gerigtheid op God het 'n spesiale karakter: dit kan moeilik beskryf word. Lukas en Paulus se uitsprake oor die paradys lewer nie sulke uitgebreide inligting soos 1 Henog en 4 Esra se uitsprake op nie. Dit is uitsprake wat met min inligting werk omdat die sake waarna dit verwys moeilik onder woorde te bring is. Met die motief van die hemelreis wil Paulus in 2 Korintiërs 12:2, 4 te kenne gee dat die ontmoeting met Christus hom wegneem uit die alledaagse, normale realiteit en vir hom verplaas in die paradys as ' $\mathrm{n}$ hoër, transendente werklikheid (Wallace 2011:257). Hierdie insig herinner weer tot ' $n$ mate aan hemelreise in apokalipse. Die hemelreis is gefokus op die uiteindelike mistieke uitkoms daarvan. Die tekste vertel naamlik van sieners wat, na hulle deur die hemele gereis het, uiteindelik die paradys en die teenwoordigheid van God op God se hemelse troon ervaar (Ode's van Salomo 11:16-17).

So ' $n$ hemelreis loop dus uit op ' $n$ visioen van God self en die ervaring van goddelike teenwoordigheid (Wallace 2011:253). Dit herinner aan die manier waarop God in Genesis 2-3 in die paradys teenwoordig is, maar ook aan die onbemiddelde teenwoordigheid van God in die paradys van Openbaring 22:1-5. Die hemelreis van Paulus is veel soberder vertel, maar ook daar

woonplek van God.

20 Kyk Hahne (2006: 152-3) en Moo (2011: 52, veral voetnoot 72).

21 Stone (1976: 414-52). Sien ook Rowland (1982: 55-56). Hy verwys na 2 Bar.4:2-3 waar God die geheim van die Nuwe Jerusalem wat saam met die paradys by God bewaar word, aan die siener meedeel.

22 Kyk Gathercole (2010) vir die uitgebreide aandag in Gnostieke tekste oor die hemelreise na die paradys as 'n reis waar die siener allerhande hindernisse moet oorkom. Hy bespreek Gnostieke tekste soos die Hemelvaart van Jesaja, die Evangelie van Maria, die Apokalips van Paulus, en die Evangelie van Philippus. Kyk Decock (2011: 189) vir 'n bespreking van die vereiste dat slegs 'n eties getransformeerde persoon die verborge geheime kan penetreer. Vir die divinisering van die regverdige tydens die visioen van God in mistieke geskrifte soos Die Evangelie van Thomas, sien DeConick (1996: 31-32). 
gaan dit om die plek waar regverdige mense gaan om met Christus verenig te word en dus vir God te sien en te ken.

Dit is op hierdie punt dat die geestelike betekenis van die paradys as ruimte na vore kom. Hemelreis-vertellings het ' $n$ numineuse karakter, want dit vertel van die oorweldigende ervaring van God se teenwoordigheid wat die siener uiteindelik ervaar. ${ }^{23}$ Dit bevestig Labuschagne (1991) se insig dat die konseptuele skeppingsmodelle in die Bybel nie in die eerste plek antroposentries is nie. Hulle regverdig, in sy oë, nie menslike heerskappy waardeur die mens apart en onafhanklik van die natuur en skepping geteken word nie. Hulle onderstreep eerder die feit dat die skepping, insluitende die mensdom, hulle betekenis in die verhouding met God vind. ${ }^{24}$

Daarom gaan die ervaring van paradys om die belewing van gebeure wat nie in menslike taal vasgevang kan word nie. "Jewish ascent narratives often portrayed the heaven in which God was encountered in language that resists literal interpretation" (Wallace 2011:259). Paulus kan nie praat oor wat hy in die paradys in die derde hemel beleef het nie (2 Kor.12:4), juis vanweë die totaal ander, transendente karakter van sy ervaring. Hy weet immers nie of dit in of buite die liggaam gebeur het nie (2 Kor. 12:3). Paulus het volgens die vertelling iets werkliks beleef, maar dit was ' $n$ onmiddellike ervaring van woorde "wat nie uitgespreek mag word" nie. Dit is 'n intuïtiewe aanvoeling en wysheid wat woorde transendeer (Wallace 2011:262). Die Pauliniese uitspraak onderstreep dus die mistieke kwaliteit van die paradys-motief. Die paradys-motief het veral in ' $n$ spirituele sin te doen met die mistieke teenwoordigheid van God onder mense en in die skepping as ' $n$ ervaring wat moeilik in woorde uitgedruk kan word. Vandaar die teruggrype op sober, teruggehoude, selfs gelaaide en simboliese motiewe. Skrywers wat die paradys-motief gebruik wil 'n kern-ervaring van geloof konseptualiseer, maar kry dit net reg deur hulle op die verbeelding van hulle lesers te beroep. ${ }^{25}$ Die oorspronklike verhaal van die paradys in Genesis 2-3 was ' $n$ motief wat lesers se verbeelding aangegryp het en daarom hier gebruik word. Hierdie spesiale siening van die paradys as plek word op ' $n$ ander manier bevestig en selfs verhelder wanneer sekere antieke skrywers kritiek lewer op ' $n$ te letterlike uitleg van die paradys-verhaal in Genesis 2-3. Wanneer Philo byvoorbeeld in ' $\mathrm{n}$ intellektuele debat met ander interpretasies van die paradys betrokke raak, skerm hy hom pertinent af van mense wat die paradys-verhaal wil verletterlik. Die paradys as tuin van Eden beteken vir hom, saam met vele ander skrywers, nie dat God letterlik in ' $n$ tuin in die koelte van die aand wandel of dat God ploeg en saai nie (Niehoff 2010:29; vgl. ook Bockmuehl 2010:209). ${ }^{26}$ Dit sou 'n kru verdraaiing van antropomorfiese spreke in die Bybel wees. Nietemin is die paradys-verhaal vir hom waarheidsgetrou en werklik (Niehoff 2010:29). Die paradys is vir hom nie ' $n$ mitiese fabrikasie nie. Dit is waarom, soos hierbo vermeld is, dat Philo die paradys in ' $\mathrm{n}$ plek buite die bewoonde wêreld plaas. Philo bevestig dus die waarheidsgehalte van die paradys deur dit in ' $n$ ruimte te lokaliseer wat menslike kaarte en metingsinstrumente transendeer.

Wanneer Paulus en Lukas die paradys-motief vanuit 'n kosmologiese hoek ruimtelik lees, het dit vir hulle veral ' $n$ geestelike dimensie. Soos Paulus, wil Lukas 23:43 die paradys uitbeeld in terme van ' $n$ vereniging met die goddelike. Jesus sê immers vir die moordenaar uitdruklik dat hy "saam met" Jesus sal wees. Duidelik word, vanuit 'n teosentriese perspektief, die werklikheid en intiemheid van die ervaring van die goddelike, wat juis die antropomorfe en kosmologiese transendeer, uitgedruk.

23 Kyk bv. Op.19:10, maar ook Op. 1:17.

24 Kyk Brümmer (1991: 16). Van besonder belang is Palmer (1991) se artikel wat beklemtoon dat die nieantropologiese perspektief op die skepping deurslaggewend is om die posisie van kerk en teologie ten opsigte van die huidige ekologiese krisis te hanteer. Kyk ook verder hier onder.

25 Kyk Decock (2011: 183-99) vir ' $n$ waardevolle bespreking oor die funksie van simbole in Openbaring. 26 Kyk bv. Reed (2006) oor 1 Henog 6-11 met sy belangstelling in kosmologie. Sy verwys na Graf (1999) se bespreking van metallurgie. 


\section{DIE PARADYS AS BESLISSENDE MOMENT}

In vele opsigte speel die paradys ' $\mathrm{n}$ beslissende rol in die geskiedenis. Later Joods-Christelike resepsies sien dit as die beslissende moment aan die begin en afronding van God se skepping en heilswerk. Die paradys bring die mens ook voor die beslissende moment om in die hede te kies vir wat werklik saak maak. Die paradys moet dus ook vanuit 'n temporele perspektief verstaan word.

\subsection{Die eerste paradys}

Die paradys-verhaal in Genesis 2-3 bly, soos reeds geblyk het, steeds weer die uitgangspunt van later Joods-Christelike resepsies en neem op die manier ' $\mathrm{n}$ fundamentele plek in. In latere resepsies word op allerhande direkte en indirekte maniere daarvan gebruik gemaak as die beginpunt van God se betrokkenheid by en teenwoordigheid in die skepping. Deur hierdie anker bly die later nadenke oor die motief en die voortgaande vertelling oor God se betrokkenheid in die geskiedenis van Israel en die nuwe volk van God steeds weer gebind aan die skeppingsverhaal, al gebeur dit in die volle wete dat die paradys vir die mensdom verlore geraak het. Die verhaal in Genesis 2-3 was vir latere lesers ' $n$ beslissende oomblik in hulle heilservaring en -vertelling en die oorspronge daarvan.

Lesers wat die verhaal van die paradys in Genesis 2-3 lees vanuit die latere perspektief van die sondvloed, sou die skeppingsverhaal sien as ' $n$ verhaal oor volmaaktheid en skoonheid. Dit is wat die goddelike bedoeling met die paradys is en wat verlore gegaan het. Die veronderstelling en insig dat God die wêreld geskep het, word gekombineer met die wete dat God daaroor bly regeer en dus dat die paradys nog in God se wil bestaan (Jes.45:6-7; Rendtorff 1992:207-8). Die eerste paradys en die verwagting van die eskatologiese terugkeer van die paradys word gevolglik ' $n$ aanduiding van die trou van God as koning en regeerder. ${ }^{27}$ God as Skepper van die aarde gee die wêreld nie op nie.

\subsection{Die toekomstige paradys}

Een van die uitstaande kenmerke van latere resepsies is hulle eskatologiese siening van die paradys. Met die koms van God se ryk, sal die paradys na die aarde terugkeer. Mense sal weer daartoe toegang kry, soos byvoorbeeld uitgespel word in Openbaring 22 as die klimatiese slot van die boek se toekomsbeeld. ${ }^{28}$ Die kosmologiese dualisme aan die begin van Openbaring met God in die hemel, afgeskei van mense op aarde, word aan die einde van die boek oorkom met die terugkeer van die paradys na die aarde (Rowland 1985:293-294; Decock 2011:195). God, die Skepper van hemel, aarde en see, was op aarde afwesig (Op. 4:11, 8; 10:6), hoewel dit juis die bedoeling was dat God as Skepper aanbid moet word (Op. 14:7). Boosheid het die mensdom en die wêreld totaal gekontamineer. Niemand is daarom in staat om die boek met die sewe seëls oop te breek nie (Op. 4). Deur die terugkeer van die paradys oorkom God die bestaande digotomie.

Ook hier word ' $\mathrm{n}$ mens met 'n nog dieper moment gekonfronteer, want die paradys het in Openbaring ' $n$ mistieke aard. Die oorkoming van die kosmologiese digotomie beteken die

27 Jesus se belofte aan die kwaaddoener is " $n$ antwoord op sy versoek dat Jesus aan hom sal dink wanneer Hy in sy "koninkryk" kom (Lk.23:42). Koninkryk word daarmee ten nouste met paradys verbind. Oor hierdie verbintenis tussen koningskap en paradys, kyk Klingbeil (2009:29): "Kingship in Israel had to do with building and maintaining the divinely created world-order. While Yahweh is the builder of Jerusalem after the Babylonian exile (Jer. 24:6), he is also the builder of Eve in Gen 2:22, whereas in both instances the lexical creation marker $h n b$, "to build" is used."

28 Moo (2011: 52) wys daarop dat reeds Eseg.47:1-2 die toekomstige tempel as " $n$ Edenagtige paradys beskryf en dus aan die paradys 'n eskatologiese kleur gee. 
direkte, onmiddellike inwoning van God in die skepping (Op. 22:5). ${ }^{29}$ Die teenwoordigheid van God bring lewe en transformeer die situasie wat ontstaan het met die verlies aan lewe in Genesis. Die paradys met die boom van die lewe en sy lewegewende waterstrome is nou weer terug (Frye \& MacPherson 2004:31).

Die eskatologiese terugkeer van die paradys is ' $n$ motief wat in vele tekste voorkom. Volgens die Apokalips van Moses 37:5 (vgl. 13:2-3; 28:4) sal mense eers weer in die laaste dae met die opstanding die paradys in al sy glorie (13:3) kan binnegaan. In 2 Henog is die paradys ' $n$ aangename, vrugbare plek in die derde hemel waar God rus, waar die boom van die lewe deur 300 lofprysende engele opgepas word en wat aan die mens as erfdeel geskenk word (Lee 2001:74-5). Beide 4 Ezra en 2 Barug gee uitgebreid aandag aan die paradys as die toekomstige heilplek vir regverdiges (Henze 2011:171-3). Die paradys bly op die manier die eindbestemming van die mens wat ook die hele skepping raak en tot sy volle ontplooiing laat kom. Dit is, trouens, 'n kenmerk van apokaliptiese tekste dat Urzeit en Endzeit, die begin en die einde, die geskiedenis en tyd omraam. Wat in die eindtyd gebeur, herstel en hernuwe wat aan die begin van alle tye gebeur en bestaan het.

Ook hierdie insig het belangrike geestelike implikasies, veral omdat dit van gelowiges ' $n$ bepaalde geloofshouding vra. ${ }^{30}$ Die paradys is naamlik die eindbestemming alleenlik van hulle wat getrou bly te midde van hulle uitdagende omstandighede. Dit geld vir pseudepigrafiese werke soos 2 Henog en 4 Ezra (Henze 2011:171-3¹). Ook die skrywer van Openbaring stel bepaalde eise aan sy lesers hieroor. Maar sy kommunikasie hieroor word deur oorreding aangevuur. Hy besef die transformatiewe potensiaal van die paradys-motief en interpreteer hulle ervaring in hulle Grieks-Romeinse konteks om sodoende hulle insig en optrede te beïnvloed en hulle met geestelike wysheid tot groter vroomheid aan te spoor. Deur ' $n$ simbool soos die paradys wil hy hulle tot volharding motiveer, eerder as met allerlei leerstellige argumente. Deur die beeld van die paradys as ' $n$ ideale heilstoestand by God spreek hy op ' $n$ inspirerende manier tot die verbeelding van sy lesers. ${ }^{32} \mathrm{Hy}$ motiveer aldus sy lesers tot gereedheid vir die deurslaggewende draaipunt in die geskiedenis. Die voorstelling van die eskatologiese paradys het selfs meer impak in die lig van antieke wysheid wat beklemtoon het dat die einde van ' $n$ mens se lewe meer beslissend is as sy begin of as die hede. ${ }^{33}$ Daarom oortref die paradys van die eindtyd die eerste paradys. Wat die mens aan die einde sal beleef, kan moeilik beskryf word. Dit is nie in woorde vas te vang nie.

Tog is ook die eskatologiese paradys slegs tot op ' $n$ punt vanuit ' $n$ antroposentriese en spirituele perspektief te verstaan. In die kosmiese denke van byvoorbeeld Openbaring is Christus die oorsprong van die skepping (Op.3:14) wat heil en vrede bring teenoor die opponente van God wat die aarde vernietig (Op. 11:18; 19:2). ${ }^{34}$ Die volharding van gelowiges is dus deel van die groter prentjie van God se herskepping waarin alles uiteindelik gaan om die heerskappy en teenwoordigheid van God. Deur die paradys-motief en sy teosentriese karakter word gelowiges bewus van die beslissende moment in die toekoms wanneer God se heilswerk tot voltooiing gebring sal word.

29 Die paradys word selfs met nie-Christelike motiewe van skrywers soos Vergilius uitgebeeld as 'n plek van ewige rus vir liggaam en siel na die dood waar volmaakte eenheid met God beleef word (Clark 2010:166-78).

30 Wat geld vir Openbaring, is, mutatis mutandis, ook waar van ander boeke. Kyk bv. Henze (2011: 171-3) vir ' $n$ soortgelyke siening in 2 Barug en 4 Ezra.

31 Kyk Decock (2011: 184, voetnoot 15) vir literatuur oor 'n regverdige lewensstyl en die kosmologiese implikasies daarvan.

32 Kyk Decock (2011: 184); Rowland (1985: 284).

33 Decock (2011: 186) verwys hier na Henze se beskrywing van 2 Bar.89:9-22 en Spr.12:1,2,6,7.

34 Decock (2011: 188). Hy verwys ook na ander apokaliptiese werke waarin die kosmiese omvang van sonde uitgespel word (bv. 1 Hen.80:2-8; 100:10-13). 


\subsection{Die bestaande paradys}

Die paradys is in Joods-Christelike tekste nie net ' $n$ saak van die verlede en toekoms nie. Die paradys word, soos reeds indirek hierbo geblyk het, as ' $n$ bestaande werklikheid beskou. Reeds op ' $n$ vroeë stadium is daar in Joodse tekste opgemerk dat die paradys, hoewel vir die mensdom verlore weens hulle oortredings, in die hemel bewaar word totdat dit 'n woonplek sou word vir die regverdiges na hulle opstanding uit die dood (2 Bar. 51:11; Bauckham 2010:43). Enkele bevoorregte sieners het volgens sommige tekste deur ' $n$ hemelreis die geleentheid om hierdie verborge paradys in die hede te ervaar. Tog was daar wel ander maniere waarop gelowiges die paradys-ervaring in die hede kon meemaak. In die Qumran-gemeenskap, byvoorbeeld, word vertel dat die regverdige reeds in die hede die heerlikheid van die paradys kan smaak, veral in die liturgiese belewing. ${ }^{35}$ Vir beide Paulus en Lukas is die paradys ' $n$ bestaande werklikheid waarin gelowiges nog voor die eindtyd kan deel. Trouens, wie die oproep tot getrouheid gehoorsaam, word op ' $n$ beslissende manier daarin ondersteun deur die wete dat hulle nou reeds deel aan God se teenwoordigheid.

Ook in sy teenwoordige karakter is daar ' $n$ teosentriese dimensie. Die ervaring van die paradys beteken ' $n$ noue en intieme ontmoeting met God. Weer pas dit in in die konteks van die tyd waarin daar ' $n$ toenemende fokus is op die vertikale dimensie van mense se geloofservaring. Ten spyte van die groot ramp wat die volk Israel met die vernietiging van die tempel in 70 n.C. oorval het en die geloofskrisis met sy vrae oor God waarin mense gedompel is, was daar heelwat dokumente waarin ' $n$ besondere vereniging met God beskryf is - soos reeds hierbo uitgewys is. In apokalitiese werke as mistieke tekste is veral ' $n$ verborge gemeenskap van God beklemtoon wat aan die einde openlik ervaar sal word en die wese van die nuwe skeppingswerklikheid sal bepaal en uitmaak. Dit is ook uitdruklik te vind in die slot van Openbaring waar die paradys die woonplek van God onder mense is, waar God en die Lam se troon sal staan en waar God die mense sal verlig (Op.22:1-5).

In die Grieks-Romeinse tyd van krisis en ontheemding, sonder tempel en land, het hierdie literatuur mense moed gegee: dit vertel hoe bevoorreg sommige uitgesoekte mense was om hierdie mistieke hemelreise te kon aflê. Meer nog het Openbaring met sy liturgiese vieringe vir mense nou reeds hierdie vereniging met God laat ervaar. Die hemelse viering in Openbaring 4-5 is die model vir wat op aarde in die kring van gelowiges gebeur.

Die paradys het dus nie te doen met ' $n$ mistieke ontvlugting van die bestaande wêreld nie. Die paradys is God se alternatief op die huidige verworde wêreld en funksioneer as kritiek op die vernietiging van God se skepping deur teenstanders van God (Op. 18). Dit vertel van ' $n$ aarde waarin God die middelpunt van aanbidding is en wat weer beantwoord aan die skeppingsdoel wat God oorspronklik daarvoor gehad het (vgl. veral Op. 14). Dit vertel ook van die teenwoordigheid van God se heil onder mense reeds in die hede.

\section{GEVOLGTREKKING}

Die voorafgaande bespreking wys hoe die paradys-motief, ten spyte van die komplekse aard daarvan in latere Joods-Christelike tekste, steeds weer onlosmaaklik met die skeppingsverhaal

35 Kyk Rowland (1985: 106-7). Hy verwys na die Oorlogsrol waarvolgens die gemeenskap, hoewel hulle in ' $n$ kosmiese stryd betrokke is, reeds deel in 'n paradys- en engele-bestaan. Ook die Ode's van Salomo 11:16 (vgl. 20:7) praat van gelowiges wat in die paradys opgeneem word. Dit gebeur veral in die liturgiese vieringe van die gemeente. Kyk verder Decock (2011: 193) en Lincoln (1981: 149) vir vele ander voorbeelde. 
verbind bly. ${ }^{36}$ Dit was die geval in Genesis $2-3,{ }^{37}$ maar, soos aangetoon is, ook in ander Bybeltekste en latere geskrifte. In resepsies van die paradys-verhaa word dus daaraan gedink as onlosmaaklik verbonde met die werklikheid van die skepping en natuur. Die paradys-motief het dus steeds ' $n$ kosmologiese karakter. ${ }^{38}$

Die kosmologiese aard van die paradys-verhaal is egter vir skrywers ten nouste met die verlossingswerk van God verbind. "Their maps chart the topography of redemption within the topography of creation" (Bockmuehl 2010:209). Joodse en Christelike skrywers onderstreep vroeg reeds dat die paradys die simbool is van God se heilsteenwoordigheid in die skepping. Die paradys onthul die spesiale karakter van verlossing as ' $n$ gawe wat van God kom en wat op die diens van God gerig is. ${ }^{39}$ Met die verlossingswerk van God word die paradys op aarde herstel en word die natuur en mens getransformeer om in die teenwoordigheid van God te bestaan en te leef. Die Joodse monoteïsme het hierdie teosentriese denke as 'n erfdeel agtergelaat teenoor die natuur-godsdienste van die antieke en die neiging om die natuur te vergoddelik of te aanbid. ${ }^{40}$ Dit is ' $n$ perspektief wat veral in kontemporêre refleksie oor die ekologiese krisis en die rol van Bybelse denke daarin, belangrik is. Juis omdat die natuur en skepping ' $n$ dieper geestelike dimensie dien en die ruimte is vir die teenwoordigheid van God, is die opdrag om vir die natuur om te gee, soveel dringender en belangriker.

\section{AANGEHAALDE WERKE}

Barr, J. 1993. Biblical faith and natural theology. The Gifford letures for 1991. Oxford: Clarendon.

Bauckham, Richard J. 1988. The apocalypse of Peter. An account of research, in W. Haase (red.) Aufstieg und Niedergang der römischen Welt. II.25.6. Berlin, New York: De Gruyter.

Bauckham, Richard J. 2010. Paradise in the Biblical Antiquities of Pseudo-Philo, in M. Bockmuehl en Guy G.

Stroumsma, Paradise in antiquity. Jewish and Christian views. Cambridge: Cambridge University Press, 43-56.

Bietenhard, H. 1979. s. v. Paradies, in TBLNT, 2, 997-998.

Bockmuehl, Markus \& Guy G. Stroumsa 2010. Paradise in Antiquity. Jewish and Christian Views. Cambridge: Cambridge University Press.

Bockmuehl, Markus. 2010. Locating paradise, in Markus Bockmuehl en Guy G. Stroumsma, Paradise in

36 In die resepsie-geskiedenis word die konkreetheid van die paradys as plek en die verband met die skepping geïllustreer deur die ernstige debat oor watter taal daarin gepraat is. Die onderliggende oortuiging in die debat is dat God die skepping deur taal tot stand gebring het. Gevolglik word nagedink oor die taal wat God, die mens en diere met mekaar in die paradys gepraat het. Siriese skrywers uit ' $\mathrm{n}$ latere tydperk het byvoorbeeld argumente aangevoer dat die oorspronklike paradys-taal Siries en nie Hebreeus was nie. Kyk Van der Wal (1995: 93-94) vir tale wat in die paradys gepraat is. Hy verwys o.a. na Becanus volgens wie Antwerps as vorm van Nederlands die paradys-taal was. Ook Kempe het, in ' $n$ satiriese artikel, gerig teen Sweedse predikante van sy tyd, beweer Sweeds is in die paradys deur God gepraat, Deens deur Adam en Frans deur die slang.

37 Sien Noort (1999) vir 'n bespreking van die Ou-Testamentiese gegewens oor die paradys. Die paradysverhaal verklaar volgens hom die huidige korrupte bestaan van die mens en die koms van die dood in die wêreld, maar wys ook terselfdertyd op die omvorming van hierdie misvormde wêreld na die oorspronklike wil van God.

38 Kyk Fletcher-Louis (2004: 69-113) en vir die kosmologiese denke in die Nuwe Testament; ook FletcherLouis (2000: 52-68).

39 Terwyl die paradys veral konkreet in Joods-Palestynse tekste van Hellenistiese tye geïnterpreteer is, was dit veral onder invloed van die Platonisme allegories gelees deur Philo van Alexandrië en, nog sterker deur Origines in die derde eeu. Origines het bv. die uitdrywing uit die paradys gelees as 'n beskrywing van die mense se geestelike geskiedenis eerder as van die geestelike geskiedenis van die mensdom. Kyk Stroumsma (2010: 11).

40 Kyk hiervoor Goodman (2010: 62-3). 
antiquity. Jewish and Christian views. Cambridge: Cambridge University Press, 192-209.

Bouma, R. 2012. 2 Corinthians 12:2-4. The Ministry Theorem. http://ministrytheorem.calvinseminary.edu. Bremmer, Jan N. 1991. Paradise: From Persia, via Greece, into the Septuagint, in Gerard P. Luttikhuizen

(red.). Paradise Interpreted. Representations of Biblical Paradise in Judaism and Christianity. Leiden: Brill, 1-20.

Brueggeman, W. 1996. The loss and recovery of creation in Old Testament theology. Theology today 53, 177-190.

Brümmer, Vincent (red.) 1991. Interpreting the Universe as Creation. A Dialogue of Science and Religion. Kampen: Kok Pharos.

Brümmer, Vincent J. 2011. Wat doen ons wanneer ons bid? Wellington: Bybelmedia.

DeConick, April D. 1996. Seek to see him. Ascent and vision mysticism in the Gospel of Thomas. Leiden: Brill. Decock, P. 2011. The transformative potential of the Apocalypse of John. Acta Theologica 15:183-99.

Delumeau, J. 1992. Un Histoire du Paradis: Le Jardin des Delices

Delumeau, J. 1995. History of paradise: the Garden of Eden in myth and tradition (New York: Continuum, 1995).

De Villiers, P.G.R. 2009. The Glory of the Son of Man in Revelation 1-3. Reflection on mysticism in the New Testament. Acta Theologica 29, 17-39.

Fletcher-Louis, Crispin H.T. 2000. Wisdom Christology and the Parting of the Ways Between Judaism and Christianity, in Stanley E. Porter and Brook W.R. Pearson (red.). Jewish-Christian Relations Through the Centuries. JSNTS 192. Sheffield: Sheffield Academic Press, 52-68.

Fletcher-Louis, Crispin H.T. 2004. The Temple Cosmology of P and Theological Anthropology in the Wisdom of Jesus ben Sira in C.A. Evans (red.). Of Scribes and Sages: Early Jewish Interpretation and Transmission of Scripture 1-2. LSTS 50; SSEJC 9; Sheffield: Sheffield Academic Press, 1, 69-113.

Fretheim, T.E. 2005. God and creation in the Old Testament: A relational theology of creation. Nashville, TN: Abingdon.

Frye, Northrop \& Jay MacPherson. 2004. Biblical and classical myths. The mythological framework of western culture. Toronto: University of Toronto Press.

Gathercole, Simon. 2010. Quis et unde? Heavenly obstacles in Gos.Thom. 50 and related literature, in Markus Bockmuehl en Guy G. Stroumsma, Paradise in antiquity. Jewish and Christian views. Cambridge: Cambridge University Press, 82-99.

Goodman, Martin. 2010. Paradise, gardens and the afterlife in the first century C.E. , in Markus Bockmuehl en Guy G. Stroumsma, Paradise in antiquity. Jewish and Christian views. Cambridge: Cambridge University Press, 57-63.

Goris H. \& Susanne Hennecke (Red.) 2005. Adam en Eva in het Paradijs. Zoetermeer: Meinema.

Hahne, H.J. 2006. The corruption and redemption of creation: Nature in Romans 8.19-22 and Jewish apocalyptic literature, London/New York: Clark

Hasan-Rokem, Galit. 2010. Erotic Eden: nostalgia for paradise, in Markus Bockmuehl en Guy G. Stroumsma, Paradise in antiquity. Jewish and Christian views. Cambridge: Cambridge University Press, 156-65.

Henze, Matthias. 2011. Jewish Apocalypticism in Late First Century Israel. TSAJ 142. Tübingen: Mohr Siebeck.

Inowlocki, Sabrina. 2010. Tertullian's law of paradise (Adversus Judaeos 2) : reflections on a shared motif in Jewish and Christian literature, in Markus Bockmuehl en Guy G. Stroumsma, Paradise in antiquity. Jewish and Christian views. Cambridge: Cambridge University Press, 103-119.

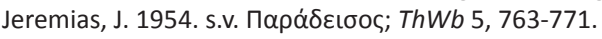

Kister, Menahem. 2010. The tree of life and the turning sword: Jewish biblical interpretation, symbols and theological patterns and their Christian counterparts, in Markus Bockmuehl en Guy G. Stroumsma, Paradise in antiquity. Jewish and Christian views. Cambridge: Cambridge University Press, 138-55.

Klingbeil, M. 2009. Creation in the Prophetic literature of the Old Testament: An intertextual approach. Journal of the Adventist Theological Society 20, 19-54

Labuschagne, Cas. 1991. Creation and the status of humanity in the Bible, in Vincent Brümmer. Interpreting the Universe as Creation. A Dialogue of Science and Religion. Kampen: Kok Pharos, 123-131.

Lee, P. 2001. The new Jerusalem in the book of Revelation: a study of Revelation 21-22 in the light of its background in Jewish tradition. WUNT 2.129. Tübingen: Mohr Siebeck.

Lincoln, Andrew T. 1981. Paradise now and not yet. Studies in the role of the heavenly dimension in Paul's 
thought with special reference to his eschatology. Cambridge: Cambridge University Press.

Luttikhuizen, G.P. 1999. Paradise interpreted: representations of biblical paradise in Judaism and Christianity (Leiden, Boston: Brill).

Macaskill, Grant. 2010. Paradise in the New Testament, in M. Bockmuehl en Guy G. Stroumsma, Paradise in antiquity. Jewish and Christian views. Cambridge: Cambridge University Press, 64-81.

Moo, Jonathan A. 2011. Creation, Nature and Hope in 4 Ezra. Göttingen: Vandenhoeck \& Ruprecht.

Moss, Yonatan, 2010. The language of paradise: Hebrew or Syriac? Linguistic speculations and linguistic realities in late antiquity, in Markus Bockmuehl en Guy G. Stroumsma, Paradise in antiquity. Jewish and Christian views. Cambridge: Cambridge University Press, 120-37.

Neville, D.J., 2007. "Towards a Teleology of Peace: Contesting Matthew's Violent Eschatology”, JSNT 30, 131-161.

Niehoff, Maren R., 2010. Philo's scholarly inquiries into the story of paradise, in Markus Bockmuehl en Guy G. Stroumsma, Paradise in antiquity. Jewish and Christian views. Cambridge: Cambridge University Press, 28-42.

Noort, E. 1999. Gan-Eden in the context of the mythology of the Hebrew Bible, in G.P. Luttikhuizen. Paradise interpreted: representations of biblical paradise in Judaism and Christianity (Leiden/Boston: Brill), 21-36.

Palmer, Martin. 1991. The ecological crisis and creation theology, in Vincent Brümmer. Interpreting the Universe as Creation. A Dialogue of Science and Religion. Kampen: Kok Pharos, 132-46.

Reed, A.Y. 2006. Beyond Revealed Wisdom and Apocalyptic Epistemology: The redeployment of Enochic traditions about knowledge in Early Christianity. Paper prepared for the Wisdom and Apocalypticism Group. SBL annual meeting.

Rendtorff, R. 1992. Some Reflections on Creation as a Topic of Old Testament Theology, in E. Ulrich, J.W. Wright, R.P. Carroll en P.R. Davies (redd), Priests, Prophets and Scribes. Essays on the Formation and Heritage of Second Temple Judaism in Honour of Joseph Blenkinsopp. JSOTSS 149. Sheffield: Sheffield Academic Press, 204-212.

Rowland, Christopher. 1982. The Open Heaven: A Study of Apocalyptic in Judaism and Early Christianity. New York: Crossroad, 1982.

Rowland, C. 1985. Christian Origins. From Messianic movement to Christian Religion. Minneapolis: Augsburg Publishing House.

Scafi, A. 1999. The notion of the earthly paradise from the Patristic era to the fifteenth century.

Scafi, A. 2006. Mapping Paradise: A history of Heaven on earth (London: British Library).

Scafi, Alessandro. 2010. Epilogue: a heaven on earth, in Markus Bockmuehl en Guy G. Stroumsma, Paradise in antiquity. Jewish and Christian views. Cambridge: Cambridge University Press, 210-20.

Schaper, Joachim. 2010. The messiah in the garden: John 19:38-41, (royal) gardens, and messianic concepts, in Markus Bockmuehl en Guy G. Stroumsma, Paradise in antiquity. Jewish and Christian views. Cambridge: Cambridge University Press, 17-27.

Stone, Michael E. 1976. Lists of Revealed Things in the Apocalyptic Literature, in Frank Moore Cross, Werner E. Lemke en Patrick D. Miller (redd), Magnalia Dei: The Mighty Acts of God: Essays on the Bible and Archeology in Memory of G. Ernest Wright. Garden City: Doubleday, 414-52.

Stroumsma, Guy G. 2010. Introduction, in Paradise in antiquity. Jewish and Christian views. Cambridge: Cambridge University Press, 1-14.

Tucker, G.M. 2009. Ecological approaches: the Bible and the land in J.M. LeMon en K.H. Richards (redd.), Method Matters Essays on the interpretation of the Hebrew Bible in honor of David L. Petersen. Atlanta: SBL, 349-368.

Van der Wal, M. 1995. Early Language Typology. Attitudes towards Languages in the $16^{\text {th }}$ and $17^{\text {th }}$ Centuries, in K.D. Dutz en K-A Forsgren (redd.) History and Rationality. Münster: Nodus.

Van Houwelingen, P.H.R. 2011. Paradise Motifs in the Book of Revelation. Sárospataki Füzetek 15, 11-25

Von Rad, G. 1936. Das theologische Problem des alttestamentlichen Schöpfungsglaubens. BZAW 66. Berlin: De Gruyter.

Wall, R. W. 1991. Revelation. Grand Rapids: Baker Books.

Wallace, J.B. 2011. Snatched into paradise (2 Cor.12:1-10). Paul's heavenly journey in the context of early Christian experience. BZN 179. Berlin: De Gruyter.

White, L. 1967. The historical roots of our ecological crisis. Science 155, 1203-1207. 
http://ngtt.journals.ac.za

Wirzba, N. 2003. The paradise of God: renewing religion in an ecological age. Oxford: Oxford University Press.

Zimmerman, Rubin. 2006. Imagery in John. Opening up paths into the tangled thicket of John's figurative world, in Jörg Frey et al. (red). Imagery in the Gospel of John. Tübingen: Mohr Siebeck.

\section{TREFWOORDE}

Paradys

Skepping

Spiritualiteit

Genesis 2-3

Lukas 23:43

2 Korintiërs 12:2

Openbaring 22:2

\section{KEY WORDS}

Paradise

Creation

Spirituality

Genesis 2-3

Luke 23:43

2 Corinthians 12:2

Revelation 22:2

\section{Kontakbesonderhede}

Prof. Pieter G.R. de Villiers

Buitengewone Professor, Departement Nuwe Testament

Fakulteit Teologie

Universiteit van die Vrystaat

Bloemfontein 9300

Epos: pgdevilliers@mweb.co.za 